\title{
Financial crises, regulation and growth ${ }^{1}$
}

\author{
Ray Barrell, Ian Hurst and Simon Kirby
}

NIESR

May 2008

\begin{abstract}
The paper discusses the possibility of a systemic banking crisis as a result of debt defaults. It looks at the vulnerability of the personal and business sectors to increases in borrowing rates, and at the evidence for a risk related rise in borrowing rates. There is an investigation of the impacts from a significant rise in the spread between lending and borrowing rates for both producers and consumers using the dynamic stochastic general equilibrium version of the National Institute global model. An increase in spreads might arise when banks wish to rebuild their capital after a crisis or reflect significant credit rationing. In either case they represent the immediate impacts of a crisis in the banking sector. The paper also investigates the impact on output of a permanent, regulation induced, rise in margins in the financial sector, taking into account the impacts of regulation on equity market valuations and on country specific risk premia
\end{abstract}

\footnotetext{
${ }^{1}$ We would like to thank Dawn Holland, Martin Weale and Phil Davis for their contributions to our understanding of this topic and to this paper in particular. The current version of this paper has benefited from comments by John FitzGerald, Wim Suyker and other participants at the AIECE meeting in Budapest on $9^{\text {th }}$ May 2008. Previous versions have been given at seminars in at the European Commission in Brussels, the Bundesbank in Frankfurt, the IMF in Washington, at the DZ Central Bankers conference in Vienna and at IfW in Kiel. We would like to thank the participants for their comments. Some of the work in this paper was initially funded by the European Commission in a project on the macro economic implications of Basel II, and the model development has been funded by the NiGEM user group, which includes the Bank of England, the ECB, the Bundesbank, the Swedish Riksbank, the IMF, the Bank of France, the Bank of Spain, the Bank of Italy and other members of the ESCB. The responsibility for the views expressed here remains ours.
} 


\section{Introduction}

A financial crisis has been building up since the summer of 2007. It has been driven by defaults on US consumer loans that have been of a sufficiently large scale as to bring the stability of the banking sector into question. Financial crises are relatively common events, but not often on the scale we are currently witnessing. They often follow periods of financial innovation or deregulation, as borrowers and lenders find themselves in situations where it is hard to evaluate the prices of new types of risk. The globalisation of financial markets has meant that the newly created assets and risks associated with them are shared across banks throughout the world and a number of European banks suffered major losses as a result of purchasing high-yield high-risk securitised mortgage backed assets originating in the United States.

In the first section, the paper looks at the vulnerability of the personal and business sectors to increases in borrowing rates, and at the evidence for a risk related rise in borrowing rates. The second section investigates the impacts of a significant rise in the spread between lending and borrowing rates for both producers and consumers in a rational expectations dynamic general equilibrium version of the widely used NiGEM model. Such an increase in spreads might arise when banks wish to rebuild their capital after a crisis or reflect significant capital rationing. The third section discusses a potential scenario for a crisis. In either case they represent the immediate impacts of a crisis in the banking sector. The final section investigates the impact on output of a permanent, regulation induced, rise in margins in the financial sector, taking into account the impacts of regulation on equity market valuations and on country specific risk premia. The paper then concludes.

\section{Background Indicators}

Financial liberalisation is often accompanied by increases in borrowing by higher risk individuals. This should increase general welfare, but also increases the risk of banking crises. Levels of borrowing differ greatly between countries, and they have been low in Italy where the personal sector debt to income ratio is around 0.6, and in France and Germany. As we can see from Figure 1 the personal sector debt to income ratio has been rising in a number of countries, and especially in the UK, Ireland and Spain. Risks of default increase as new borrowers with no history of borrowing build up liabilities on which their default risk is unknown.

Between the start of 1998 and the end of 2007 the borrowing to personal income ratio in the UK rose by 48 per cent or 0.46 of personal disposable income, whilst in Germany it fell marginally. The absolute and proportional increases were larger in Ireland and Spain than in the UK, but they were smaller in the US and France. Increases in debt to income ratios on this scale are in part the result of financial liberalisation, but are also due to the low inflation and low real interest rate environment established over the past decade. Gross interest payments on debts would have risen less than these numbers indicate, especially in the UK and Ireland where interest rates are currently 16 per cent and 26 per cent respectively below the levels of the first quarter of 1998. Interest rates rose by around 25 per cent in France and Germany of this period, raising the debt service ratio. 
Figure 1 Personal sector borrowing as a proportion of disposable incomes

(Central bank sourced financial account, consolidated except for Ireland)

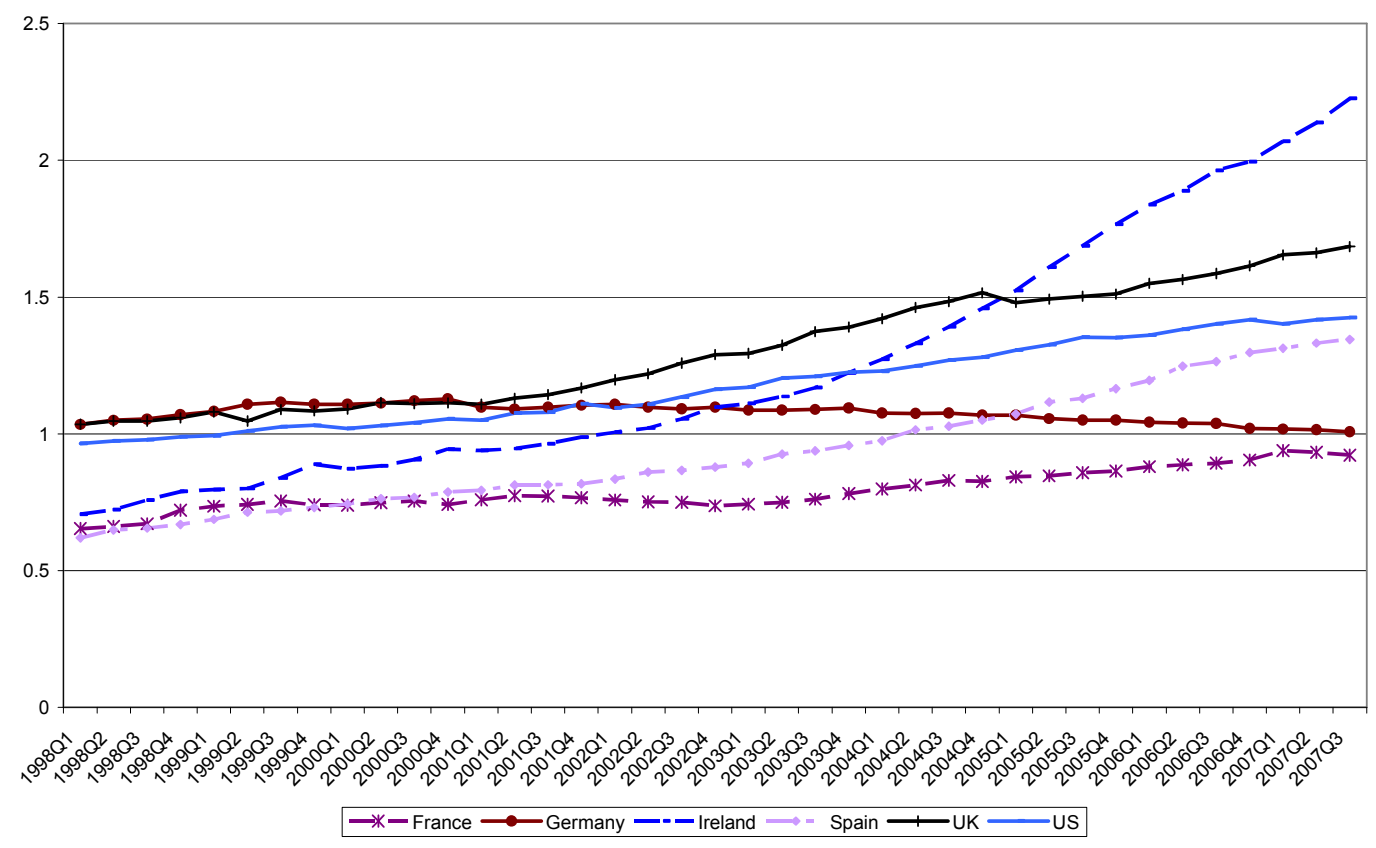

Increases in perceived lending risks can lead to higher borrowing margins. Personal income would be affected by the margin as it includes gross income receipts on deposits and other assets held with the financial sector (PA) at an average rate of $r_{d}$ minus interest payments (at $r_{d}+$ margin) on liabilities to the financial sector (PL) where margin is the difference between borrowing and lending rates for the personal sector. We may write net interest receipts as

$$
\mathrm{NIR}=\mathrm{r}_{\mathrm{d}} * \mathrm{PA}-\left(\mathrm{r}_{\mathrm{d}}+\text { margin }\right) * \mathrm{PL}
$$

When assets exceed liabilities it is possible that an increase in interest rates raises other personal income, although it would reduce incomes when debts are larger. An increase in the spread between borrowing and lending rates for consumers always reduces incomes, and hence consumption.

The effect of increases in borrowing rates depends on the structure of borrowing by firms and individuals. Table 1 reports on the proportion of consumer debt that is based on housing, and also the proportion of the mortgage debt that is at fixed rates. The proportion of total debt that is fixed is reported in column three, and this is multiplied by the debt to income ratio to give a borrowing cost vulnerability indicator in Figure 2 . Personal incomes would be most affected by a rise in borrowing costs in Ireland and Spain, followed by the UK and Denmark. Germany and France have small proportions of floating rate borrowing as a per cent of personal disposable incomes and hence are likely to be less vulnerable to increases in borrowing rates. 
Table 1 Borrowing percentages for the personal and corporate sectors

\begin{tabular}{|c|c|c|c|}
\hline $\begin{array}{l}\text { Share of } \\
\text { adjustable } \\
\text { rate } \\
\text { mortgage } \\
\text { debt } \\
\text { Stock in } \\
2005\end{array}$ & $\begin{array}{l}\text { Share of } \\
\text { mortgages } \\
\text { in total } \\
\text { debt }\end{array}$ & $\begin{array}{l}\text { Fixed } \\
\text { rate } \\
\text { loans } \\
\text { as a per } \\
\text { cent of } \\
\text { total } \\
\text { loans }\end{array}$ & $\begin{array}{l}\text { Equity } \\
\text { capitalisation } \\
\text { as a per cent } \\
\text { of the value } \\
\text { of business } \\
\text { sector capital } \\
\text { stock }\end{array}$ \\
\hline 14.0 & 79.8 & 68.6 & 53.13 \\
\hline 16.0 & 66.2 & 55.6 & 20.24 \\
\hline 17.0 & 65.9 & 54.7 & 25.77 \\
\hline 28.7 & 72.9 & 52.0 & 41.32 \\
\hline 35.0 & 74.7 & 48.6 & 48.44 \\
\hline 37.9 & 61.4 & 38.1 & 34.72 \\
\hline 54.0 & 75.7 & 34.8 & 46.41 \\
\hline 84.0 & 70.0 & 11.2 & 20.79 \\
\hline 84.7 & 81.2 & 12.4 & 22.98 \\
\hline 92.9 & 72.1 & 5.1 & 37.89 \\
\hline 98 & 6 & 2 & 29.76 \\
\hline
\end{tabular}

Netherlands

Germany

Denmark

France

United

States

Sweden

United

Kingdom

Italy

Ireland

Finland

Spain

98.3

66.6

Source OECD Economic Outlook December 2006 for liabilities.

Own calculations for equity capitalisation from NIESR database, data for 2006 except Denmark and Sweden, 2004

Figure 2 Personal sector borrowing cost vulnerability

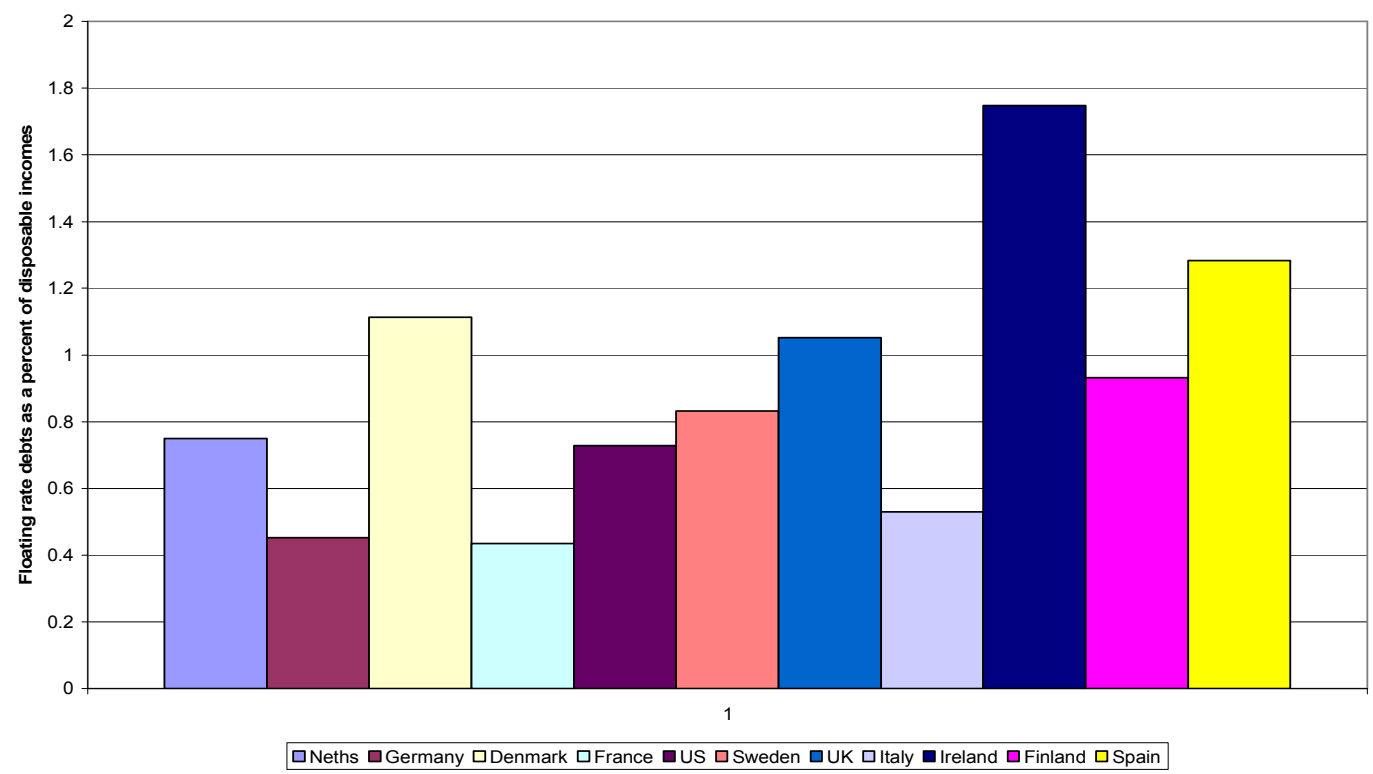


The standard Hall-Jorgenson definition of the user cost of capital (user) in equation 2 below depends on the weighted average of equity and bond finance (Brealey and Myers 2000). Table 1 reports on the ratio of the value of the equity market to the value of the business sector capital stock (eqs) and this can be used as the weight on equity finance in the user cost. The rate of return on equity capital can be gauged by the earnings price ratio in the stock market $(\mathrm{cec})$. The cost of bank and bond finance can be gauged by the rate of return on of corporate bonds, which is made up of the real return on risk free government bonds $(l r)$ plus a corporate spread (spread).

$$
\text { User }=((\text { eqs } * \text { cec }+(1-\text { eqs }) *(1 r+\text { spread }) *(1-c t)+\text { dep }+ \text { pt }) /(1-c t))
$$

where $c t$ is the corporate tax rate, $d e p$ is the depreciation rate, $p t$ is the rate of change in capital goods prices, and interest payments are tax deductible. The more dependent firms are on equity markets the less vulnerable they are to increases in borrowing costs as long as real equity prices remain constant. Corporate sector vulnerability to increases in borrowing costs is likely to be highest in Germany, Italy and Ireland since they have the lowest stock market to capital stock ratios and hence probably the highest levels of corporate sector borrowing from banks and other lenders ${ }^{2}$.

Large levels of debt do not necessary presage a crisis, and indeed banking crises are difficult to predict accurately. However, large levels of debt make the impact of a rise in borrowing rates more difficult for an economy to sustain, and may make the financial system unstable when problems emerge. If lending has been unwise, as appears to be the case in the US sub-prime market, default rates might be high, and as a result the value of bank assets may fall below their liabilities and the banks are technically bankrupt. If there are worries about the ability of banks to meet their obligations the borrowing rates they face in the inter-bank market might rise to levels that make them operate at a loss, and hence cause their capital base to shrink.

Banking crises are not rare events, and often follow periods of financial liberalisation. Barrell, Davis and Pomerantz (2006) list the recent crises used in IMF and World Bank studies of their impacts. They record six major banking crises amongst the 18 established European countries between 1980 and 1999. Hoggarth and Sapporta (2001) discuss the empirical evidence on the costs of banking crises, and suggest that the GDP impacts can be large. They stress the impact of the crisis on the cost of finance for firms and hence on investment in the economy. Financial assets also get destroyed in banking crises and wealth declines, and as a result consumption spending declines. Barrell, Davis and Pomerantz (2006) look at the additional impact of crises on consumer spending after taking account of both lower income and lower wealth, and they show that there is an additional and large effect from changes in the behaviour of lenders. Credit rationing increases in a crisis and this reduces consumption more than predicted by falls in income and wealth, suggesting that credit rationing effects are present in consumer behaviour in banking crises. They also show that the negative effect of rationing are greater the larger the scale of personal sector indebtedness.

2 The tax treatment of corporate bonds may be one of the reasons for excess issuance of complex securities. 


\section{The Crisis in the US}

The most recent crisis in the US has been widely discussed, and we describe it briefly. Financial innovation resulted in lending to increasingly risky borrowers, while the lender could shift risk (the originate and distribute model) completely. Poor quality US loans were bundled and sold on but were difficult to value by conventional means. Because barriers to the movement of financial capital have largely been removed, markets spread risk to other countries where the poor quality of US borrowing and bankruptcy regulation was not fully understood. Most mortgages in the US are non-recourse loans, as Weale (2008) points out. Although they are secured on property, there is no personal liability. A borrower who buys a second home, for instance, has a pure call-option with a strike price equal to the mortgage. If the price of the house falls below the strike price then the borrower walks away costlessly. This in itself would not be a problem if those buying the mortgage backed securities had understood this but they clearly did not. Non-recourse loan default does not require bankruptcies takes place, but even when they do there are still problems for lenders as it remains difficult to recapture the full value of loans ${ }^{3}$. Borrowers, who default on recourse loans, or on their own house, are allowed to keep housing equity up to $\$ 125,000$ or more if they are below median incomes ${ }^{4}$. US bankruptcy laws are meant to encourage risk taking, and they have, but unfortunately in housing markets, the risky assets have been sold on to financial institutions who do not understand them ${ }^{5}$.

Default rates on many loans have risen, and the scale of losses is large and is made immediate by 'mark to market' valuations. As a result, bank balance sheets will have to contract. Estimates of $\$ 400$ billion losses on $\$ 1000$ billion of subprime loans have been made by Greenlaw, Hatzius, Kashap and Shin (2008), with half of those losses becoming apparent by early $2008^{6}$. More recent work by the Bank of England (2008) suggest that ultimately losses may be less than this, in part because the market value of some mortgage backed securities that contain defaulting loans have fallen below reasonable estimates of their final redemption value.

In its Global Financial Stability Report the IMF (2008) suggested that the losses on low and medium quality loans by the US and financial sectors in other countries could total around $\$ 1000$ billion. It is possible that falling house prices could induce US consumers to default on prime loans issued to good creditors with significant housing equity, and US bankruptcy law is generally such that many consumers could choose this option. It is also possible that default rates on credit cards and car loans could rise, but perhaps this is less

3 Defaulting on a mortgage creates fewer problems than default on credit cards and on car loans, as borrowers will withdraw facilities or blacklist people. Not being able to but another second home quickly is much less of a problem than not being able to but or lease a new car. Hence we would expect default rates to be much lower

${ }^{4}$ The level of assets that can be retained vary from state to state, and are above this level in most cases.

5 One reason for very low interest rates in the US in early 2008 despite inflation risks was to reduce defaults in the personal sector. Barrell (2008) argues that lax bankruptcy laws give US monetary policy makers an inherent inflationary bias as compared to the Euro Area. As a result these laws may have contributed to the excess volatility of the US economy.

${ }^{6}$ Three different approaches are utilized. They look at the term structure of defaults on subprimes, which have risen as high as 20 per cent, and they have been rising, and they show they have been worsened by house price falls. They also look at defaults on mortgage backed securities as so far announced, and get a similar figure to that given by their previous method. Finally, they discuss similarities with previous regional housing market downturns in the US, and extrapolate this experience to the whole economy 
likely as the short-term costs are perhaps higher. In addition it is possible that borrowers with negative equity in the UK and elsewhere might choose to default on their loans when house prices are falling and, if they did, banking sector losses could mount ${ }^{7}$. We do not see this as a central scenario, but rather choose to analyse it as a possibility.

Greenlaw et al. (2008) suggest that half of the bad loans have remained in the US financial sector in the hands of leveraged institutions, and some, perhaps a third, have been bundled up and shifted offshore. They estimate that the US financial system had reserves of $\$ 1681$ billion and assets of $\$ 20,485$ billion in 2007 , with $\$ 1100$ billion of the reserves being held by commercial banks with assets of $\$ 10,793$ billion. A loss of $\$ 200$ billion would represent around an eighth of all reserves ${ }^{8}$ and this could be recouped by raising lending margins by 1 to 2 percentage points more than they otherwise would increase for one or two years ${ }^{9}$. If losses were as high as $\$ 1000$ billion this would represent 60 per cent of all reserve assets.

When leveraged institutions such as banks lose part (or all) of the value of their capital base they have to find ways to rebuild it reduce their loan portfolio. If most banks in a market have lost some of their capital asset base and choose to reduce their loan books then the supply curve for loans will shift up the demand curve for loans. The price of loans increases with a greater spread between loans and deposits. Leverage will improve as their asset base will rise with higher earnings and their loan book will shrink. Another way to rebuild their base is to make rights issues, but these are unlikely to succeed unless banks are clear that they are taking better account of risk in future and that losses have been fully identified. This information failure during a financial crisis can be seen as the major aspect of capital market failure. Financial crises also lead to changes in the perception of risk, in part because crises are often the result of pricing risk too cheaply. In general risk premia will rise in crises, and this will lead to an increase in the spread between borrowing and lending rates.

Increasing premia on risky assets will be reflected in the spread between borrowing and lending rates, as will the reduction in the supply of loans. Firms and individuals will face higher borrowing costs for a given deposit or central bank intervention rate, and the personal sector will find its net interest receipts (receipts on its gross deposits less payments on its gross loans) reduced. Figure 3 plots the spread between government bond rates and BAA bond rates in Europe and the US. These spreads have risen by around 200 basis points everywhere, suggesting that private sector producers risks are being reevaluated everywhere. As a result the cost of capital has risen, with the impact across countries depending on the relative weights on equity and bond finance.

\footnotetext{
7 Default and repossession rates on borrowing in the UK at the peak of the early 1990s housing market crisis were a quarter of those currently observed in the US, and they were three times higher than those seen in 2007. Although reform of bankruptcy laws in 2002 has lead to a 3 fold increase in personal sector insolvencies over 5 years, there has been little increase in mortgage debt default as they are recourse loans in the UK and default requires house repossession

8 The current crisis may be the largest since the second world war in absolute terms, but not as a proportion of banking sector reserves, where it is clearly exceeded by losses in Finland and Sweden in 1991 to 1992.

9 Margins have increased because of an increase in provision for risk, and they would need to rise more to replenish reserves.
} 
Figure 3 BAA corporate bonds minus 10 year government bond yields

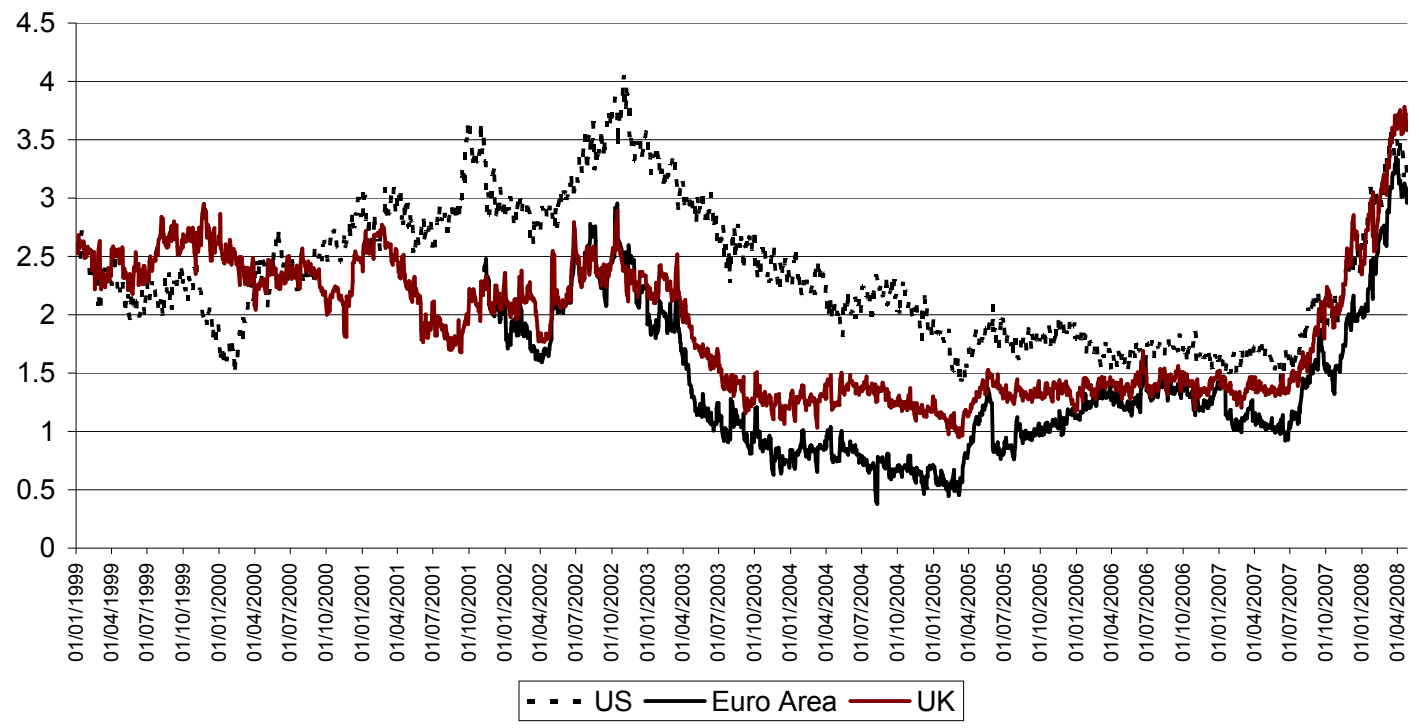

Figure 4 Mortgage spreads in the US

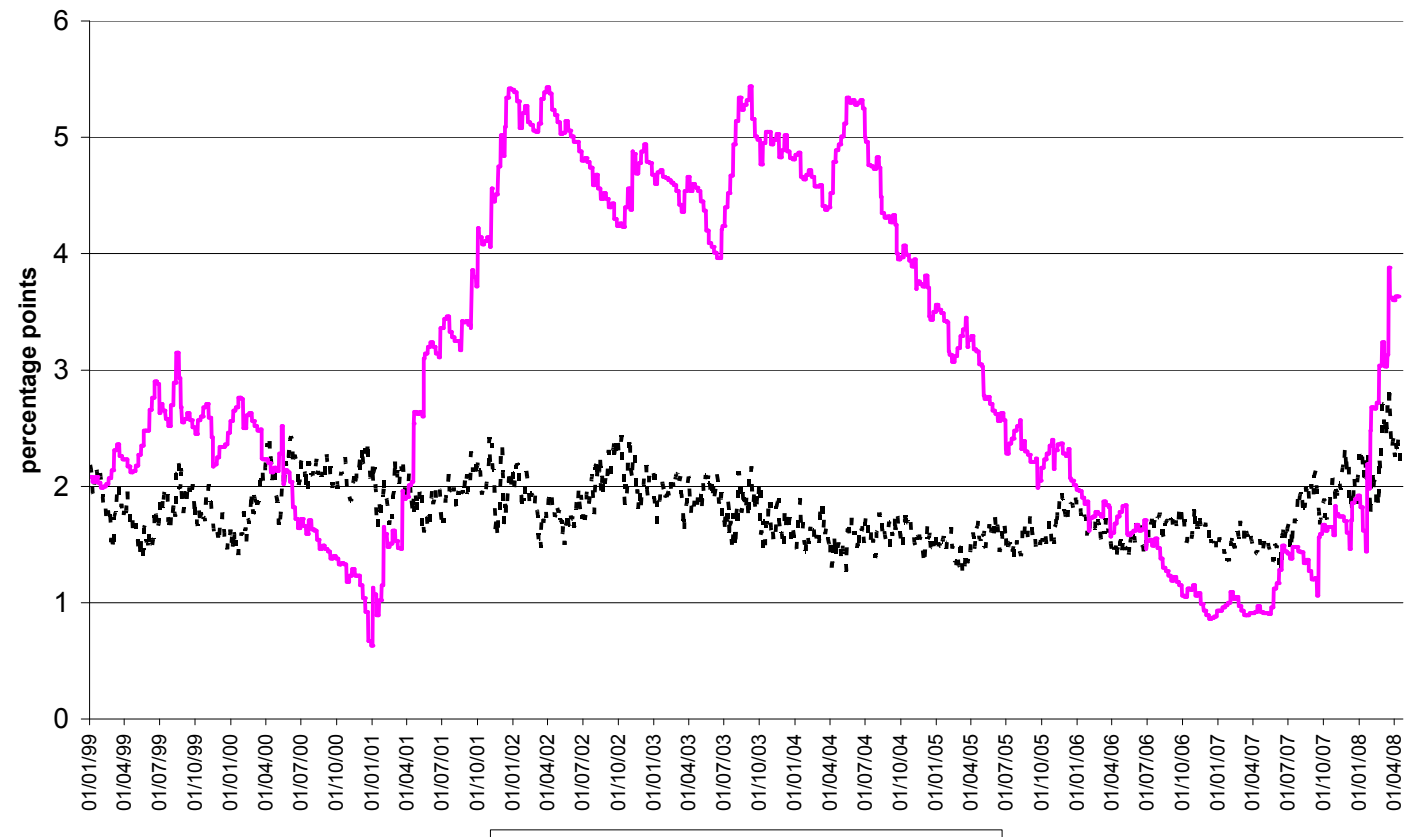

During the crisis the spread between consumers borrowing and lending rates has risen, and this will reduce income and consumption. Figure 4 plots the margin between the intervention rate and the long rate and an indicator of good quality mortgage costs in the US. This margin has also been rising, but has not yet returned to levels we saw after the last slowdown in the US. There has been little upward movement margins elsewhere, but they have been rising on new borrowing, and lending standards are being tightened. An increase in the cost of borrowing by consumers will raise the user cost of housing and will potentially impact directly onto the price of houses. Hence, a rise in the spread 
between borrowing and lending rates faced by consumers reduces the value of housing wealth, much as the reduction in this spread in many countries between 2003 and 2007 contributed to the rise in housing wealth. The fall in housing wealth may in turn reduce consumption further if consumers have been in the habit of consuming out of it. ${ }^{10}$.

\section{Diagnosing a crisis}

It is useful to investigate the potential impacts of increases in spreads and margins using NiGEM. The model can be used in various ways, and here we choose to use it in the dynamic stochastic general equilibrium version that is equivalent to the model described in (Harrison et al, 2005). The long run structure is based on the same theoretical framework, and the dynamics of adjustment to that equilibrium are estimated or the result of rational expectations jumps ${ }^{11}$.

Output $(Q)$ is determined in the long run by supply factors, and the economy is open and has perfect capital mobility. The production function is CES, where output depends on capital $(K)$ and on labour services $(L)$ which is a combination of the number of person in work and the average hours of those persons. Technical progress (tech) is assumed to be labour augmenting and independent of the policy innovations considered here

$$
Q=\alpha\left(\delta(K)^{-\rho}+(1-\delta)\left(L e^{\lambda t e c h}\right)^{-\rho}\right)^{-1 / \rho}
$$

We assume forward looking behaviour in production and because of 'time to build' issues investment depends on expected trend output four years ahead and the forward looking user cost of capital. However, the capital stock does not adjust instantly, as there are costs involved in doing so. ${ }^{12}$ The elasticity of substitution is estimated from the labour demand equation, and in general it is around 0.5. This estimate is used in the calibration of the other parameters of the production function, and an estimate of technical progress is calculated. Prices are determined as a constant mark-up over marginal costs in the long term, and are consistent with factor demands, and are influenced by capacity utilisation.

Capacity output is determined by the production function, and if output is above capacity producer prices rise more rapidly. We may write capacity output YCAP as dependent on the actual capital stock $\mathrm{K}$, and the steady state level of labour services.

$$
Y C A P_{t}=\gamma\left[s\left(K_{t}\right)^{-\rho}+(1-s)\left(L_{t} e^{\lambda t e c h_{t}}\right)^{-\rho}\right]^{-1 / \rho}
$$

A change in the rate of technical progress will change the capacity output of the economy. Labour markets are described in Barrell and Dury (2003) and embody rational expectations. Wage dynamics depend upon the error correction term in the equation and on the split between lagged inflation and forward looking inflation expectations as well as on the impact of unemployment on the wage bargain.

10 The evidence on the effects of house prices on consumption is discussed in Barrell and Davis (2007), and their work suggests that changes in house prices have more impact in the UK, the US and Spain than in France, Germany or Italy

11 The adjustment speeds may be slightly slower and more realistic as Barrell and Kirby (2007) suggest

12 The approach to the estimation of the production function is set out in Barrell and Pain (1997). 
It is assumed that consumers react to the present discounted value of their future income streams which we may call total wealth $(T W)$, although they may face liquidity constraints from their personal disposable income in the short run.

$T W_{t}=Y_{t}-T_{t}+T W_{t+1} /\left(\left(1+r r_{t}\right)\left(1+m y_{t}\right)\right)$

where $Y$ is real income, $T$ are real taxes. The variable with suffix $\mathrm{t}+1$ is an expected variable, and it is discounted by the real interest rate $r r$ and by the risk and myopia premium used by consumers, $m y$. The equation represents an infinite forward recursion, and permanent income is the sustainable flow from this stock. The dynamics of adjustment may depend on financial and housing asset based wealth ${ }^{13}$. Total wealth and permanent $(P I)$ income can be linked by the stock flow relationship where $\gamma$ is the rate of return on the perpetuity $T W$.

$P I_{t}=\gamma * T W_{t}$

The dynamics of adjustment to the long run are important in policy analysis and they are largely data based, and differ between countries to take account of differences in the relative importance of types of wealth and of liquidity constraints. Barrell and Davis (2007) discuss the impact of financial liberalisation on the dynamics of adjustment in a group of countries where housing wealth can be utilized for borrowing.

Financial wealth depends on foreign and domestic equity and bond prices and on the accumulation of assets. Each country on the model has a stock of foreign assets and a stock of liabilities linked to the stock of domestic financial assets and the stock of domestic private sector and public sector liabilities. A proportion of government debt is owned abroad, as are proportions of the national stock of equities and the stock of banking assets. Some national financial wealth is held in foreign equities and bonds as well as banks. Income flows from asset stocks are allocated in relation to ownership, and hence net property income from abroad depends on income receipts and payments on bonds, equity holdings and bank. The wealth and accumulation system allows for flows of saving onto wealth and for revaluations of existing stocks of assets in line with their prices determined as above. When foreign equity and bond prices change, domestically held assets change in value.

Exchange rates are forward looking in the uncovered interest parity condition. The current exchange rate depends on the expected future path of interest rates and risk premia. Interest rates are determined by policy rules adopted by monetary authorities ${ }^{14}$ :

$$
R X_{t}=R X_{t+1}\left[\left(1+r h_{t}\right) /\left(1+r a_{t}\right)\right]\left(1+\operatorname{rprx}{ }_{t}\right)
$$

where $R X$ is the exchange rate, $r h$ is the home interest rate, $r a$ is the interest rate abroad and rprx is the risk premium. Relationships of this form are investigated empirically in $\mathrm{Al}$

13 House prices on the model depend in the long run on the user cost of housing capital, and this is affected by the mark-up over risk free rates, much as the user cost of business capital depends on the investment premium.

${ }^{14}$ See Barrell and Dury (2000) for a discussion of monetary and fiscal policy rules in NiGEM. 
Eyd, Barrell and Holland (2006) and the implications for risk premia for the evolution of current accounts are discussed in Barrell, Holland and Hurst (2008). Bond and equity markets are also forward looking, and long-term interest rates are a forward convolution of expected short-term interest rates. Forward looking equity prices (eqp) are determined by the discounted present value of profits net of corporate taxes (prof). The discount factor includes the equity risk premium on (prem)

$$
e q p_{t}=\operatorname{prof}_{t}+e q p_{t+1} /\left[\left(1+r h_{t}\right)\left(1+\operatorname{prem}_{t}\right)\right]
$$

The monetary rules on the model determine $r h$ and are discussed in Barrell, Hall and Hurst (2006). The rules contain forward looking expectations of the rate of inflation. All countries have fiscal closure rules, as discussed in Barrell and Sefton (1997). Budget deficits are kept within bounds in the longer term through a targeted adjustment of income tax rates.

\section{The crisis}

The current financial crisis appears to be concentrated mainly in North America and Europe. Japan seems to be largely unaffected and we do not include it in our diagnostics. Table 2 gives the impact of a shock to the investment premium that feeds into the user cost of capital in the countries affected. A two hundred basis point rise in the investment premium, which is around that seen in the past six months, sustained for one year, reduces GDP growth by up to a quarter of a percentage point for two years. Fiscal and monetary policy feedback rules are in place, and wage bargainers, financial and foreign exchange markets are forward looking with model consistent rational expectations and forward looking consumers take account of future income prospects as well as current income. Bond prices depend on the forward looking yield curve, and equity prices are the discounted future value of future profits, whilst the exchange rate follows the arbitrage path. The effects of the rise in spreads is larger in the Euro Area countries than in the UK and the US because investment finance is more band and bank based, whereas the other two countries rely more on finance through the issue of equities.

\section{Table 2 Impacts of an increase in the investment premium of 200 basis points for one year in North America and Europe}

\begin{tabular}{rrrrrrrr}
\multicolumn{7}{c}{ GDP percent difference from baseline } \\
2008 & US & UK & Euro Area & Germany & France & Spain & Italy \\
2009 & -0.21 & -0.14 & -0.24 & -0.24 & -0.24 & -0.23 & -0.21 \\
2010 & -0.24 & -0.30 & -0.48 & -0.42 & -0.45 & -0.53 & -0.55 \\
2011 & 0.00 & -0.16 & -0.23 & -0.15 & -0.19 & -0.28 & -0.42 \\
2012 & 0.07 & -0.06 & -0.07 & -0.04 & -0.05 & -0.05 & -0.25 \\
& 0.05 & -0.01 & 0.00 & -0.01 & 0.00 & 0.08 & -0.09
\end{tabular}

The spillovers from the banking system crises to investment do not appear to be large, but the same probably cannot be said of the effects on consumption, at least in the UK and the US. As a diagnostic we increase the spread between borrowing and lending rates by 200 basis points for one year in each of the Euro Area countries, in Sweden and Denmark, the UK, the US and Canada, and the results are reported in table 3 . If we were 
to see this happen, then growth would slow most rapidly in the UK, US, and Spain. This reflects both the importance of gross interest payments in the economy and the importance of house prices in determining consumption. Personal sector borrowing is currently about two thirds higher in the UK and the US than in Germany and France and more than double that in Italy, hence an increase in borrowing costs driven by a higher margin between borrowing and deposit rates will have proportionately greater effects in the UK and the US than in the other economies ${ }^{15}$. Spanish borrowing levels are around 85 per cent of those in the UK, whilst the Netherlands has a burden that is around 15 per cent higher than in the UK. The effects would be almost twice as large if we assume consumers are myopic and do not consumption smooth in relation to the discounted present value of their future incomes ${ }^{16}$.

Table 3 Impacts of an increase in the mortgage markup of 200 basis points for one year in North America and Europe

\begin{tabular}{rrrrrrrr}
\multicolumn{7}{c}{ GDP percent difference from baseline } \\
2008 & -0.21 & -0.20 & -0.15 & -0.15 & -0.15 & -0.16 & -0.08 \\
2009 & -0.27 & -0.22 & -0.12 & -0.06 & -0.10 & -0.25 & -0.14 \\
2010 & 0.02 & -0.03 & 0.00 & 0.04 & 0.02 & -0.02 & -0.11 \\
2011 & 0.12 & 0.08 & 0.06 & 0.05 & 0.06 & 0.14 & -0.05 \\
2012 & 0.12 & 0.11 & 0.07 & 0.04 & 0.06 & 0.20 & -0.01
\end{tabular}

These counterfactual impacts depend in part on the impacts on house prices, and these are reported in table 4 . However, there are many other factors involved in the determination of house prices, and in the current environment these may overlay the simple effects of a higher user cost. House prices do not have the same effect on consumption everywhere. There is clear evidence that short-term fluctuations in house prices affect consumption in the UK and the US, but there is little evidence of an impact in Germany or Italy. This may reflect the nature of the housing market and the lack of any real possibility of borrowing against housing wealth, especially in Italy. There is also little evidence that borrowing margins are rising in France, Germany or Italy. Hence we would not expect growth to weaken these as much as these diagnostic simulations suggest. However, the possibility exists and we turn to discuss a more substantial crisis below.

Table 4 Impacts of an increase in the mortgage markup of 200 basis points for one year in North America and Europe

\begin{tabular}{rrrrrrrr}
\multicolumn{7}{c}{ House prices \% diff from baseline } \\
US & UK & Germany & & US & UK & Germany \\
2008 & -1.49 & -1.29 & -1.52 & 2008 & -1.49 & -1.29 & -1.52 \\
2009 & -2.84 & -2.52 & -2.90 & 2009 & -2.84 & -2.52 & -2.90 \\
2010 & -1.70 & -1.51 & -1.72 & 2010 & -1.70 & -1.51 & -1.72 \\
2011 & -1.09 & -0.97 & -1.03 & 2011 & -1.09 & -0.97 & -1.03 \\
2012 & -0.72 & -0.66 & -0.63 & 2012 & -0.72 & -0.66 & -0.63
\end{tabular}

15 Based on personal sector liabilities as a proportion of nominal GDP

${ }^{16}$ Barrell and Hurst (2008) discuss similar scenarios with myopic consumers, and we reproduce some of their results as an appendix 


\section{Manufacturing a crisis}

If the US banking system were to lose $\$ 1000$ billion then the impact would depend on the speed with which reserve assets have to be rebuilt, the way in which they are rebuilt and the extent to which globalised financial markets have shifted risks offshore. Losses of this scale cannot be seen as a main case, and they are not built into our baseline. It is possible to analyse the additional $\$ 600$ billion losses suggested as possible by the IMF as a worst case scenario. If we assume around a third of the losses will have been passed on, then banking sector margins in the US would have to rise by $2 \frac{1}{2}$ to 5 percentage points for one to two years to recoup the losses. In addition, the greater scale of losses would mean that increased provisions for risk would be needed to be made in margins and borrowing costs would rise by more than the amount needed to rebuild capital.

In order to evaluate the impacts of the crisis we analyse a scenario where we increase the spread between consumers' borrowing and lending rates in the US by 500 basis points, and where we also increase the spread facing firms in the US by 250 basis points. Spreads must rise elsewhere in the world by half as much as in the US ${ }^{17}$, but we assume only. Both increases are implemented for two years and they are applied to the US, Canada, and the European economies. The scenario is run from the first quarter of 2008 over a 30 -year base. The impacts on quarterly growth rates for the US, the UK and the Euro Area are set out in figures 4 to 6 .

\section{Figure 5 Financial Crisis and Growth in the US}

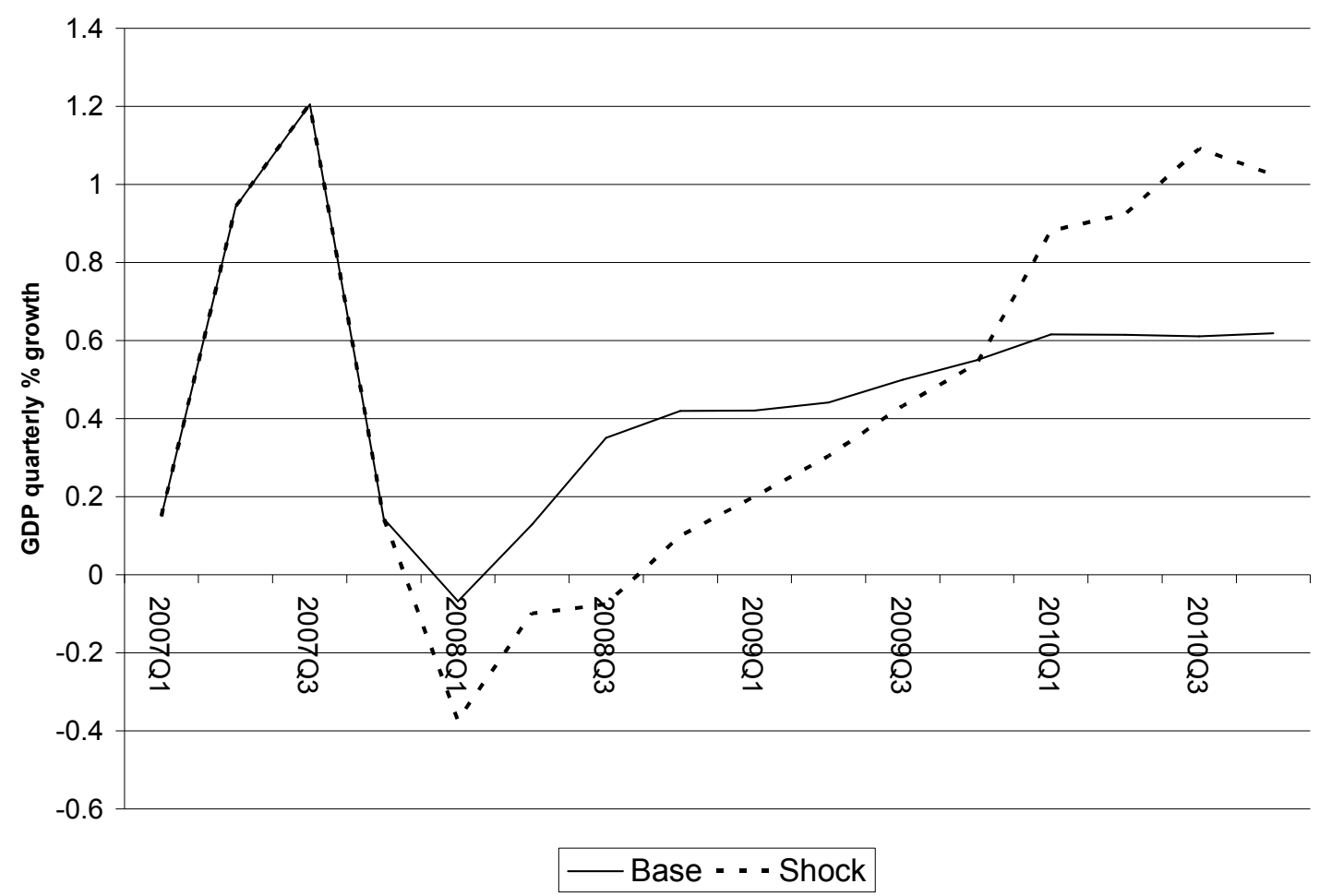

17 In many European countries the losses may have been taken on by nationalised banks and hence the taxpayer will directly replenish the loss, and the impacts on bank lending will be less. 
Figure 6 Financial Crisis and Growth in the Euro Area

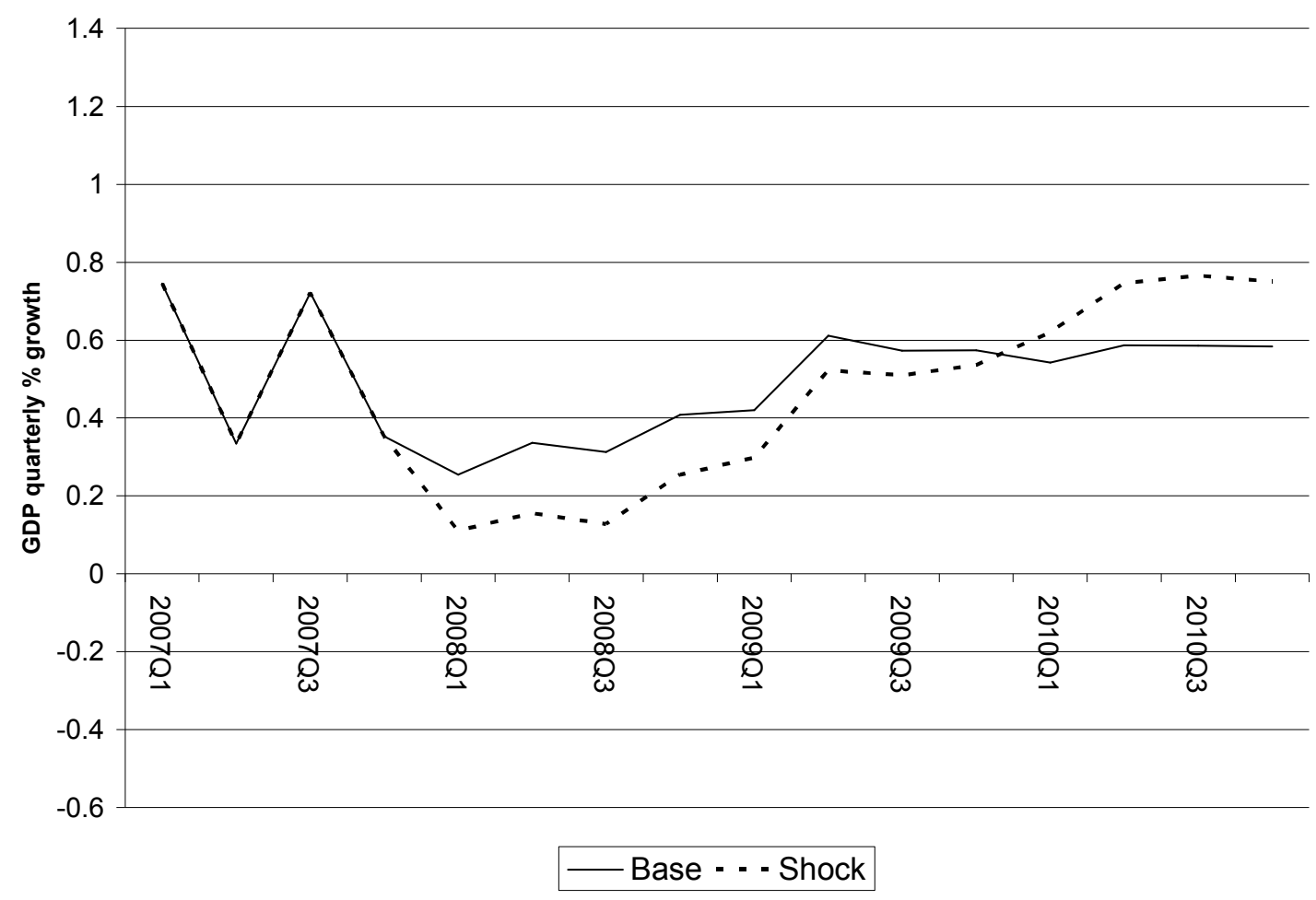

Figure 7 Financial Crisis and Growth in the UK

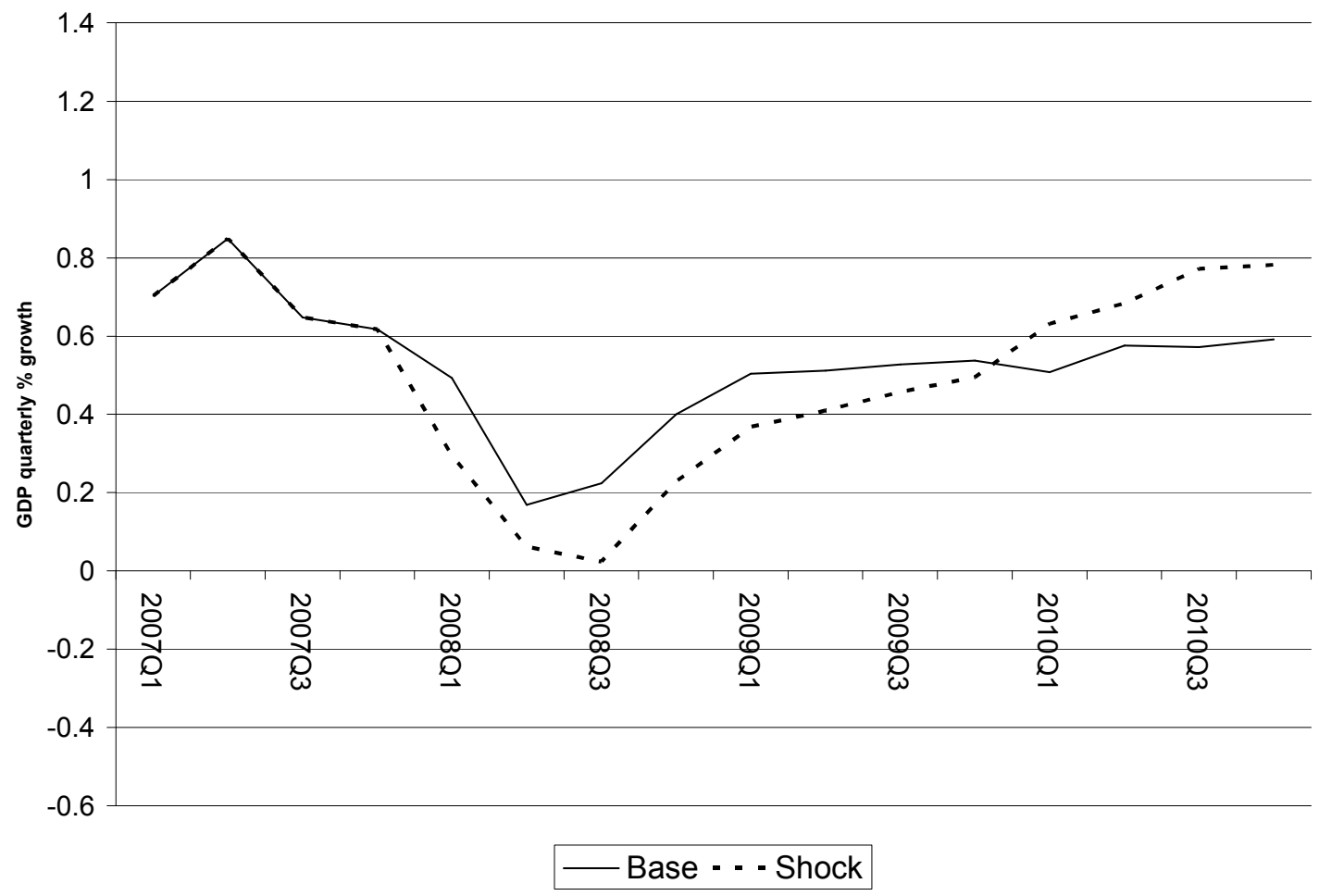




\section{Table 5 Impacts of the Financial Crisis}

\begin{tabular}{rrrrrrrr}
\multicolumn{7}{c}{ GDP percent difference from baseline } \\
2008 & US & UK & Euro Area & Germany & France & Spain & Italy \\
2009 & -0.80 & -0.70 & -0.69 & -0.74 & -0.69 & -0.70 & -0.47 \\
2010 & -1.68 & -1.55 & -1.51 & -1.31 & -1.44 & -1.90 & -1.48 \\
2011 & -0.88 & -1.16 & -1.14 & -0.70 & -0.98 & -1.63 & -1.79 \\
2012 & 0.42 & -0.16 & -0.24 & 0.00 & -0.12 & -0.17 & -1.20 \\
& 0.74 & 0.38 & 0.21 & 0.17 & 0.22 & 0.82 & -0.55
\end{tabular}

A financial crisis on this scale would halt US growth during this year, and the annual rate of growth would drop to around 0.5 per cent per annum as compared to 1.3 on our core forecast, and to 0.8 per cent in 2009 as compared to our base forecast of 1.7 per cent.. The effects on other countries would depend on where the losses were felt and how much they affected the banking system. If we spread the losses evenly then growth in the UK would also slow, this year and next, and we might see growth as low as 1.1 per cent this year and lower than 1 per cent next year as compared to 1.8 per cent in each year in our baseline. On the same basis Euro Area growth might slow to around 0.8 per cent in each year and 1.1 next year as compared to 1.5 per cent and 1.9 per cent in our baseline. These falls could be compounded if there were domestic problems in these countries as well as in the US.

In our scenario the US experiences a technical recession of two quarters of negative growth. However, if the effects on margins were to come through more quickly, perhaps because of weakness in the housing market, then it would be easy to generate a more significant slowdown in the short term. Indeed, this has been a worry for the Federal Reserve and low interest rates are partly designed to reduce defaults in the housing market. The potential inflationary risks have been accepted, at least for the time being. Europeans have generally chosen tighter bankruptcy laws and lower inflation risks than the US and we would expect this to continue. If the crises were to deepen beyond that suggested by the IMF, the major way in which it would be propagated would continue to be through financial market effects.

Financial crises are difficult to avoid without major impacts on the prospects for financial innovation and economic growth. Financial innovation can reduce borrowing costs and this will reduce the user cost of capital, hence, for a period at least, it can be important for raising growth ${ }^{18}$. However, it is difficult to distinguish between sustainable innovation and excessive risk taking. Regulators have to ensure they encourage the former and discourage the latter. Financial sector regulation is extremely difficult and financial innovation often finds ways around regulation. However, good regulation revised to keep up with developments is essential if financial markets are to be constrained from generating a depression on the scale seen between 1929 and 1933.

18 There is an extensive literature on financial innovation and also one on banking crises. The literatures on these two topics are discussed in Kroszner, Laeven and Klinggebiel (2007). 


\section{Cost and benefits of bank regulation in the UK}

Changes in bank regulation change the structure of bank costs, and the implications can be analysed using dynamic stochastic general equilibrium models. If banking markets are competitive these changes in costs will be passed on to the users of bank services in either increased costs for using services or increased charges on loans. These in turn will affect behaviour, and change consumption and investment. The best way to model these implications is to presume that the change in costs comes through as an increase in the margin between borrowing and lending rates. The change in costs and the increase in margins, or spreads, will affect both consumers, who both deposit money and borrow from banks, and firms who finance part of their investment from bank or market related borrowing.

\section{The impacts of changes in bank margins}

The impact of a change in bank margins on firms depends upon its impact on the user cost of capital and hence on the level of the desired capital stock. It is possible to calculate the user cost with the standard finance formulae which takes the average cost of equity finance and bank (or other sources of) finance and adjusts this for depreciation and corporate taxes. In the UK the value of the stock market is about half the value of the private sector capital stock, which suggests that on average British firms finance about half of their investment from the stock market and half from either internal funds or from external borrowing. The user cost of capital in the UK is around 13 to 14 per cent, well above risk free untaxed rates. If banks were to raise their margins permanently by 0.50 per cent (50 basis points) then, before second round effects were taken into account, the user cost of capital facing firms would rise by about half this number and the desired capital stock (and the sustainable level of output) would be smaller, with the impact depending upon the elasticity of substitution between capital and labour. It is very unlikely that banks would only raise costs to firms, as they have no profit related incentive to do this. Hence, we would expect the margin between borrowing and lending rates facing consumers to increase by a similar amount to that faced by firms.

Overall an increase in bank costs as a result of increased prudential regulation will lead to a fall in consumption and national saving will rise. Domestic investment will also fall and real interest rates will be marginally lower, but the main effect will be small as the UK is a small open economy without capital controls. The major consequence of the increased national saving with lower domestic investment will be an improvement in the current account of the balance of payments and a gradual accumulation of foreign assets.

Table 6 The effects of a permanent 50 basis point rise in spreads in the UK (\% difference from base)

Year 1

Year 2

Year 3

Year 4

Year 5

Average 10-14

Average 15-20

Average 21-25

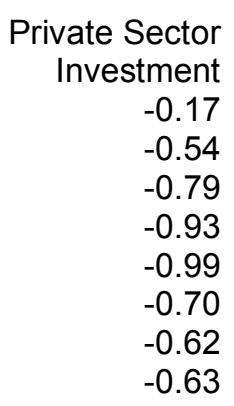

Output

$-0.23$

$-0.51$

$-0.67$

$-0.75$

$-0.78$

$-0.68$

$-0.60$

$-0.54$
Output
-0.02
-0.08
-0.14
-0.18
-0.20
-0.17
-0.17
-0.18 
Table 6 details the impacts on consumption and investment as well as on GDP. A rise of 50 basis points in the spread between borrowing and lending rates would reduce output in the long run by around $1 / 5^{\text {th }}$ of a percent, all else equal. As long as all consumers and investors fully understood the policy output growth would be lower by about one third of this for three years and would then stabilise on its new trajectory, with the trend growth rate then being unchanged as it is driven by population and technology. Private sector investment would be about $2 / 3^{\text {rds }}$ of a per cent lower, whilst public sector investment is assumed to move in line with trend output in the long run. Consumption would also fall by around $1 / 2$ to $3 / 4$ of a per cent as compared to baseline, which would be rather more than the fall in income. The increase in saving, along with the lower level of private sector investment, would result in an improvement in the balance of payments. Assets would accumulate abroad, and the income flow on them would mean that consumption would start to grow relative to domestic output.

Our analysis is undertaken with a standard interest rate reaction function for the central bank. The slower growth over a number of years would leave room for a small cut in interest rates, and given our assumption that financial markets are forward looking and fully understand the implications of the changes sterling would immediately decline by around two percent, boosting net exports and reducing the impacts of the increase in spreads on the economy.

Good bank regulation is difficult, and as it reduces output, at least at first glance, it is unpopular. Liquidity ratio regulation may be easily avoided by moving items off balance sheet, even at a small cost, but it may be of use. Changing the asset quality rules for judging capital adequacy is also possibly useful. Perhaps the most effective change in regulations would come from requiring that secured loans (by anybody) could not have more than (say) 90 per cent recourse to the security in case of a default on the loan. Lenders would then be unwilling to lend at low rates above this ceiling. Asset bubbles would be less common, and securitised assets less vulnerable to default

\section{Offsetting effects from equity markets}

Our assumption that all else would be equal means that in this analysis there are no second round implications for either bank equity prices or for the risk premium associated with investing in assets in the UK as compared to elsewhere. Both may change as a result of the change in bank regulation that increases the spread, and the effects of these changes would help offset the impacts of the change, and might even be larger, giving an overall positive outcome. The equity premium should fall, boosting the stock market and investment, and the general volatility of the economy should be lower, and this should lead to a lower country specific risk premium and hence to overall lower real interest rates.

Changes in bank regulation can reduce systemic risk, and hence reduce the risk premium applied to the evaluation of bank profits, and this would raise the price of their equities. We model equity prices as the discounted future value of profits, and the discount rate depends upon the equity premium. On average in the UK this is around 7 percent or so, given current $\mathrm{P} / \mathrm{E}$ ratios, risk free interest rates and expected growth rates. The equity 
premium exists in part because there are risks associated with holding equities, some of which are associated with default risks, and some with an aversion to the volatility of returns associated with profits based income streams. Bank regulation may change the default risk for banks and hence reduce the risk premium. If we assume that new regulations reduce the default risk from one year in 40 to one year in 80 then the risk premium associated with bank shares would fall by 1.25 percentage points. Overall the equity premium in the UK would fall by less than this, but banks and other financial institutions make up a substantial part of the equity base, and we assume that around a sixth of all assets on the stock market would be affected. Banks acting on their own could not produce this increase in their equity price, as the default risk is largely systemic. It is widely acknowledged that wise regulation could have positive effects for bank shareholders as well as for the economy in general. A reduction in the risk of bank failure may also reduce risks for others, and all equity premia may fall somewhat.

We have undertaken an analysis of the impacts of a fall in the equity premium of 50 basis points on the assumption that bank profits are, as a first round effect, unchanged by the new regulations as all the extra costs are passed on to customers. As Table 7 shows, output would rise in the medium term by around the same amount as the fall seen as a result of the increase in spreads as a consequence of legislation on banks. The combination of stronger output and higher equity prices would mean that consumption would rise by a half of the fall seen as a direct consequence of legislation. Investment would also rise because the user cost of capital would fall by approximately half the fall in the equity premium.

Table 7 The effects of a permanent 50 basis point fall in equity premium in the UK ( $\%$ difference from base)

Year 1

Private Sector Investment

Year 2

Year 3

Year 4

Year 5

Average 10-14

Average 15-20

Average 21-25
0.23
0.67
0.93
1.10
1.18
1.07
0.99
1.01

Consumption
\[ \begin{array}{r}0.21 \\ 0.26 \\ 0.25 \\ 0.24 \\ 0.24 \\ 0.24 \\ 0.24 \\ 0.25\end{array} \]

Output

0.06

0.09

0.11

0.12

0.13

0.18

0.21

0.24

Offsetting effects from country specific risk

The offsetting effects of a fall in the risk premium on equities can be relatively plausibly scaled, but it is less clear what the scale of the effects on the country specific risk premium might be. In a world with forward looking financial markets the exchange rate today depends upon the exchange rate expected next period, on the interest differential between the UK and elsewhere and on any risk premium that might be needed in the arbitrage conditions. Good regulation reduces the country specific risk premium in this arbitrage relationship, and raises the sustainable level of output as a lower risk premium results in lower real interest rates. Increases in debts and banking sector risks associated with them raise risk premia, as do increases in current account deficits driven by consumption. 
These phenomena have been factors behind the fall in the dollar over the last five years, as Barrell, Holland and Hurst (2008) discuss. They suggest that the risk premium on US assets has been slowly rising over the last 5 years, driving the dollar downwards. We can apply a similar analysis to the UK, but with a reverse sign if we believe that bank regulation will improve prospects and reduce the UK's country specific risk premium. We have undertaken a scenario where the country specific risk premium falls by 40 basis points a year. This is larger than the effects decline in the default risk for banks would indicate, as we wish to give a menu of offsets, and wish to avoid spurious accuracy.

Table 8 The effects of a 40 basis point fall in the UK country specific risk premium (\% difference from base)

Year 1

Year 2

Private Sector
Investment

0.07

0.28

0.51

0.75

Year 4

Year 5

Average 10-14

Average 15-20

Average 21-25
0.97

1.64

1.64

1.63
Consumption

0.06

0.00

$-0.06$

$-0.10$

$-0.11$

$-0.15$

$-0.18$

$-0.21$
Output

$-0.09$

$-0.19$

$-0.21$

$-0.18$

$-0.13$

0.16

0.26

0.32

A 40 basis point fall in the country specific risk premium for the UK would induce a fall in long term real interest rates of around 20 basis points, and the real exchange rate would appreciate initially by about 4 per cent. The fall in long real rates would reduce the user cost of capital and also induce equity and bond prices to rise. Both of these would raise the level of demand in the short term but as we can see from Table 8 this would not be quite enough in the first few years to offset the effects of the stronger exchange rate. However, in the longer term sustainable output would be higher. If there were no effects from country specific risk premia then the output effects of our scenarios would be about zero. Any such risk premia effects would raise costs in the short run but increase the benefits in the long run.

Increased prudential requirements raise costs, and increase margins. Figure 8 plots the impacts on output of a 50 basis point rise in the spread between borrowing and lending rates for consumers along with a 50 basis point increase in the premium investors would have to pay on their bank borrowing. However, good regulation should reduce default risk and hence the equity premium, and figure 8 also plots the impact on output of a fall of a comparable magnitude. The two effects would offset each other. In addition, better regulation would reduce the country specific risk premium in the forward looking exchange rate. This would induce an appreciation of the exchange rate which would initially reduce output as compared to base because of the competitiveness effects, but the lower risk premium will lead to lower real interest rate sand hence a higher capital stock and a higher level of output, as we can see from figure 8 . 
Figure 8 The impact on output of a 25 basis point rise in spreads between borrowing and lending rates in the $U K$

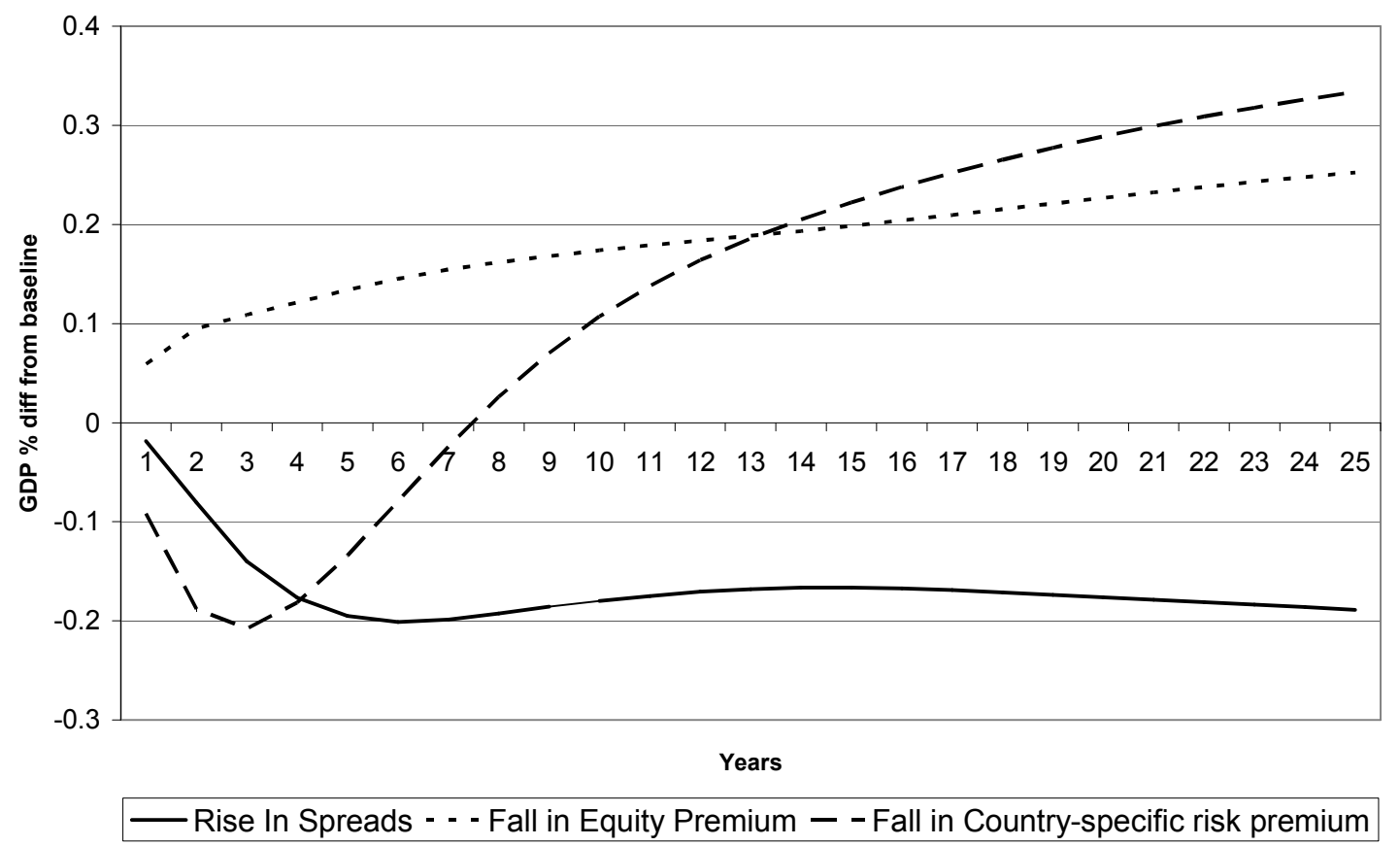

\section{Conclusion}

The recent financial crisis that has emanated from the US mortgage market has been driven by excessively risky lending disguised by complex financial products. Default rates have risen as high as 20 per cent. Losses have worn away at the capital base of the banking system in the US and the UK. If the losses are as large as the upper end estimates then we are in the middle of the largest financial crisis since the Second World War. The complex products were sold to people inside and outside the US who did not understand the risks they were taking, and they have lost money. There are calls for improvement in regulatory structures and for coordinated actions. Coordination of bankruptcy law is probably as important as coordination of regulation, and should be considered. Coordination of European regulators should also be discussed, as countries do not have full oversight of their banking systems in the current dispersed responsibility structure ${ }^{19}$.

There are ways to give incentives for banks to follow regulations, and hence reduce debts Regulators will always need to innovate in response to the market, but they should not give up the task because it is hard. Financial markets improve the efficiency of the economy and the welfare of citizens. Regulation can make them operate more effectively but also induce costs. Although the direct effects of regulation might be to reduce output and consumption marginally the general reduction in risk in the economy could have beneficial effects that could more than offset the costs. A quantification of impacts on margins and default risk is needed before a cost benefit can be fully undertaken.

\footnotetext{
${ }^{19}$ Country regulators look at liquidity needs of foreign banks but do not supervise their capital adequacy, and hence must remain ignorant of many risks that banks on their soil take.
} 


\section{REFERENCES}

Al-Eyd, Ali, Ray Barrell and Dawn Holland, (2006) 'A portfolio balance explanation of the euro dollar rate' The Travails of the Eurozone ed D Cobham, Palgrave

Bank of England (2008) Financial Stability Review

Barrell, R., (2008) 'Financial Crises and Global Prospects' National Institute Economic Review, no 204 pp 9-13

Barrell, R., Byrne J., and Dury K., (2003) 'The implications of diversity in consumption behaviour for the choice of monetary policy rules in Europe' Economic Modelling vol 20 pp 275-299

Barrell, R. and Davis, E.P. (2005), 'Policy design and macroeconomic stabillity in Europe', National Institute Economic Review, 191, pp. 94-105.

- (2007), 'Financial liberalisation, consumption and wealth effects in 7 OECD countries', Scottish Journal of Political Economy, May.

Barrell, R., Davis, E.P. and Pomerantz, O. (2006), 'Costs of financial instability, household-sector balance sheets and consumption', Journal of Financial Stability, 2, 2, pp. 194-216.

Barrell, R., and Dury, K., (2000a) 'An Evaluation of Monetary Targeting Regimes' National Institute Economic Review, No. 174, October 2000.

Barrell R., and Dury, K. (2003) 'Asymmetric labour markets in a converging Europe: Do differences matter?' National Institute Economic Review No. 183, January 2003

Barrell, R., Hall. S., and Hurst, I., (2006) 'Monetary Policy Rules Economics Letters p1-6

Barrell, R. and Holland, D. (2007), 'Banking crises and economic growth', National Institute Economic Review, 302, pp. 34-41.

Barrell, R., Holland, D. and Hurst, A.I. (2008), 'Sustainable adjustment of global imbalances', in Aslund, A. and Dabrowsk, M. (eds), Challenges of Globalization Peterson Institute of International Economics.

Barrell R., and Hurst A. I., (2008) 'Financial crises and the prospects for recession. National Institute Economic Review no. 204 April 2008 pp 33-38

Barrell R., and Kirby, S., (2007) 'Interest rates and the UK economy'. National Institute Economic Review no. 202 October 2007 pp 61-64

Barrell, R., and N. Pain (1997), "Foreign Direct Investment, Technological Change, and Economic Growth Within Europe", Economic Journal, 107, pp. 1770-1776.

Barrell, R., and Sefton, J. (1997) 'Fiscal Policy and the Maastricht Solvency Criteria', Manchester School, June

Brealey, R., and Myers S., (2000) 'Principles of Corporate Finance' MacGraw Hill

Greenlaw, D., Hatzius, L., Kashap, A. and Shin, H.S. (2008), 'Leveraged losses: lessons from the mortgage market meltdown', US Monetary Policy Forum, February.

Hoggarth G and Sapporta V (2001), "Costs of banking crises, some empirical evidence", Financial Stability Review, June 2001, 148-161, Bank of England, London

Harrison, R., Nikolov, K., Quinn, M., Ramsay, G., Scott A., and Thomas, R., (2005) 'The Bank of England Quarterly Model' Bank of England, 2006

IMF (2008), Global Financial Stability Report, April.

Kroszner, R., Laeven, L. and Klinggebiel, D. (2007), 'Banking crises, financial dependence and growth', Journal of Financial Economics, 84, pp. 187-228.

Weale, M., (2008) 'The Banking Crisis and the Economy' National Institute Economic Review, no 204 pp 4-8 


\section{Appendix The effects of a rise in the mortgage margin with myopic consumers}

In the main text we assume that consumers are forward looking and react to future events. This is a suitable assumption when analysing policy options, as we do in the final section of the main paper. In banking crises individuals may be constrained from reacting to future developments and may be able to consume only in relation to current incomes, as they may not be able to borrow. Our modelling strategy for myopic consumers involved estimating error correction consumption equations, as in Barrell, Byrne and Dury (2003), Consumption depends on current income and wealth and some dynamic adjustment to the long run. In forward mode we replace current income and wealth with permanent income. We use the dynamics of adjustment to the long run given by the estimated equation.

We can switch between backward and forward consumers easily, with changes to results coming only from this switch. We repeated the experiment in Table 3 where we increased the mortgage margin for a year by 200 basis points but switched to backward looking consumers, and we report the results in Table A1. If policy makers wish to be cautious in a crisis they should look at the constrained consumer results as well, as the forward looking consumer will smooth away a large portion of the effects of the crisis. They may be constrained from doing this and our analysis must allow for this worse case scenario.

Table A1 Impacts of an increase in the mortgage markup of 200 basis points for one year with myopic consumers

\begin{tabular}{rrrrrrrr}
\multicolumn{8}{c}{ GDP percent difference from baseline } \\
US & UK & Euro Area & Germany & France & Spain & Italy \\
2008 & -0.23 & -0.24 & -0.17 & -0.19 & -0.16 & -0.19 & -0.07 \\
2009 & -0.52 & -0.45 & -0.29 & -0.31 & -0.23 & -0.47 & -0.15 \\
2010 & -0.31 & -0.30 & -0.20 & -0.21 & -0.17 & -0.32 & -0.14 \\
2011 & -0.12 & -0.14 & -0.08 & -0.09 & -0.10 & -0.09 & -0.07 \\
2012 & 0.01 & -0.01 & 0.02 & -0.01 & -0.03 & 0.13 & 0.01
\end{tabular}

Compare to table 3 in main text - Nigem simulation 